\title{
Some New Chromosome Numbers in the Mesembryanthemae
}

\author{
H. P. Riley and D.R. Varney \\ Department of Botany, University of Kentucky, \\ Lexington, Kentucky, U.S.A.
}

Received June 9, 1967

\section{Introduction}

The family Ficoidaceae Juss. or Aizoaceae $\mathrm{A}$. Br. as frequently construed, comprises a number of succulent and non-succulent genera that are found primarily in southern Africa. The family names, however, are not used consistently. The term Ficoidaceae sometimes includes only the old Linnaean genus Mesembryanthemum and its horde of more recent segregates, but at other times may be used for these genera plus about a dozen others of less succulent nature. For all the genera once classified under Mesembryanthemum L., Jacobsen (1955) uses the term Mesembryanthema, or Mesembyranthemums, intended as a non-technical term and not as a family of the Plant Kingdom; Rowley (1951) includes those genera in his conception of Ficoidaceae Juss. em. G.D. Rowley. To distinguish between Ficoidaceae Juss. and Aizoaceae A. Br. on the one hand and his narrower conception of the Ficoidaceae (Ficoidaceae Juss. em. G.D. Rowley) on the other hand, Rowley uses the terms 'greater family' and 'lesser family', respectively, also in a non-technical sense. To avoid confusion between Mesembryanthemum L. and Mesembryanthemum L. em. L. Bol., Rowley (Jacbosen, 1960 at p. 922) would substitute "Ficoids" for Jacobsen's non-technical term Mesembryanthema. The Ficoids or Mesembryanthema are a succulent group; Brownanthus and Psilocaulon are stem-succulents but the others are considered leaf-succulents, although some of them use stems as well as leaves as water-storing organs.

Chromosome studies have been made of almost half the genera of the Mesembryanthemums by about fifteen different cytologists, but the most extensive studies have been those of de Vos (1947) and Snoad (1951). Out of slightly over 200 species studied so far, about 73 per cent are diploids, about 23 per cent are tetraploids, seven plants are hexaploids, a few are triploids, and one is a dodecaploid.

\section{Materials and methods}

Plants used in this investigation were raised from seeds supplied in 1965 by the National Botanic Gardens of South Africa at Kristenbosch, Cape Province, and are listed here according to the names under which they were received. It is hoped that herbarium specimens will be made later, but these plants are slow growing and do not flower for several years after seed germination. If and when herbarium specimens are made, they will be placed in an acceptable herbarium and identified by the voucher numbers listed in this paper. The seeds were germinated on moist filter paper in sterilized petri dishes. Germination occurred readily, often within three days. From five to ten seedlings of each species were studied.

The chromosomes that were counted were in the meristematic cells of root tips. The roots were cut off about a centimeter from the end, placed for three hours in paradichlorobenzene at $10-20^{\circ}$, fixed for $24 \mathrm{hrs}$. in a solution of three parts $95 \%$ ethanol and one part glacial acetic acid, hydrolyzed in normal $\mathrm{HCl}$ for $15 \mathrm{~min}$. at $60^{\circ} \mathrm{C}$., stained in the Feulgen stain at $10-12^{\circ}$ until the apcies became colored, placed in $1 \%$ acetic-orcein, and squashed under a cover glass. The paradichlorobenzene was used to shorten the chromosomes, hold the dividing cells in 
metaphase, and give the appearance of a better spread; but occasionally it was necessary to tap on the cover glass with the blunt end of a dissecting needle to spread the chromosomes satisfactorily. Ten cells or more were studied in each root- tip.

While this technique usually produced excellent preparations, it was occasionally necessary to leave the root tips in a one per cent acetic-orcein solution for as long as $20 \mathrm{~min}$. to obtain adequately stained chromosomes. There is some variation in the reaction of chromosomes of different species to the stain, but the method outlined above was generally the most satisfactory. Aceto-orcein alone frequently stained the cytoplasm too deeply and aceto-carmine was generally ineffective.

All the technical work was carried out by the junior author under the direction and quidance of the senior author who is also responsible for writing up this report.

\section{Observations}

The chromosomes of forty-seven species and varieties that had not previously been reported were studied. These taxa belong to fourteen genera, seven of which had not previously been studied cytologically. All these species and varieties are diploids. Two other species undoubtedly are polyploids, but because of the large number of chromosomes and because of the difficulty of getting them spread adequately, an exact determination was not made on either. They are at least tetraploids and may be even higher polyploids.

The chromosome numbers that were determined are listed below with a voucher number for each species or variety that is listed.

I. Diploid species only $(2 n=18)$

A. Species in genera of which the chromosome numbers have not previously been recorded.

Herreanthus meyeri Schwant. (65132)

Jacobsenia hallii L. Bol. (65135)

Kensitia pillansii (Kensit) Fedde (65137)

Rabiea albinota (Haw.) N.E.Br. (65210)

R. difformis(L. Bol.) L. Bol. (65210)

Semnanthe lacera (Haw.) N.E. Br. (65213)

Stoeberia carpiana (65218)

S. littlewoodii M.H.L. Bol. (65219)

B. Species which have not previously been studied in genera in which the chromosome number had been determined for other species.

Aloinopsis hilmari (L. Bol. )L. Bol. (6551).

Carpobrotus muirii (L. Bol.) L. Bol. (6563)

Cephalopyllum alstonii Marl. (6564)

Lampranthus amoenus (S.D.) N.E. Br. (65138)

L. formosus (Haw.) N.E. Br. (65143)

L. godmaniae (L. Bol.) L. Bol. (65145)

L. haworthii (Don.) N.E. Br. (=Erepsia haworthii (Don.) Schwant. (65146)

L. littlewoodii H.M.L. Bol. (65147)

L. spectabilis (Haw.) N.E. Br. (65149) 
L. uniflorus (L. Bol.) L. Bol. (65151)

L. zehyeri (S.D.) N.E. Br. (65153)

Lithops bella (Dtr.) N.E. Br. (65155)

L. bromfieldii L. Bol. (65156)

L. christinae de Boer (65157)

L. divergens L. Bol. (65159)

L. erniana Loesch et Tisch. (65161)

L. gracilidelineata Dtr. (65162)

L. hallii de Boer (65163)

L. herrei L. Bol. (65165)

L. insularis L. Bol. (65167)

L. julii Dtr. et Schwant. (65168)

L. julii var. littlewoodii (65169)

L. karasmontana Dtr. et Schwant. (65170)

L. kuibisensis Dtr. ex Jacobsen (65171)

L. marginata $\mathrm{Nel}$ (65174)

L. marmorata (N.E. Br.) N.E. Br. (65175)

L. mennellii L. Bol. (65176)

L. meyeri L. Bol. (65177)

L. olivacea L. Bol. (65178)

L. salicola L. Bol. (65185)

L. schwantesii Dtr. (65186)

L. turbiniformis (Haw.) N.E. Br. (65188)

Machairophyllum albidum (L.) Schwant. (65196)

M. altifolium L. Bol. (65197)

M. styaneri H.M.L. Bol. (65198)

M. uniondalense (65199)

Trichodiadema mirabile (N.E. Br.) Schwant. (65223)

C. Variety which has not previously been studied in species in which the chromosome number had been determined for another variety.

Cephalophyllum pillansii var. grandiflorum L. Bol. (6570)

II. Polyploid species (exact chromosome number not determined): Species which have not previously been studied cytologically:

Aloinopsis peersii (L. Bol.) L. Bol. (=Cheiridopsis noctiflora (B. gr.) L. Bol.) (6552).

Aptenia lancifolia H.M.L. Bol. (6553)

Although a large number of species of Mesembryanthemae have been studied by Snoad (1951), Miss de Vos (1947), and other cytologists, including the present report, there is no good evidence for a chromosomal basis for evolution in the group. There are no differences in base numbers, no aneuploid plants have been observed and reported, and apparently all chromosomal aberrations, other than polyploidy, are absent or at least scarce. Polyploids have been found in a number 
of genera, but they seem to occur sporadically and they seem not to indicate any trend.

\section{Summary}

1. Chromosome numbers are listed for forty-nine species and varieties not previously studied cytologically.

2. Two of the species studied are polyploids and the others are diploids.

3. Chromosome numbers are listed for seven genera of which chromosome numbers have not previously been reported.

\section{References}

Jacobsen, H. 1955. Handbuch der sukkulenten Pflanzen. Gustav Fischer, Jena.

Jacobsen, H. 1960. A Handbook of Succulent Plants. Trans. by H. Raabe and G.D. Rowley. Blandford Press, London.

Rowley, G.D. 1951. Studies in Ficoidaceae. National Cactus and Succulent Journ. 6: 27.

Snoad, B. 1951. Chromosome numbers of succulent plants. Heredity 5: 279-283.

Vos. M.P. de 1947. Cytological studies in genera of the Mesembryanthemae. Ann. Univ, Stellenbosch A 25 : 1328. 